\title{
ROLA WOJEWÓDZKICH OŚRODKÓW RUCHU DROGOWEGO W REALIZACJI ZADAŃ SAMORZĄDU WOJEWÓDZTWA W ZAKRESIE BEZPIECZEŃSTWA RUCHU DROGOWEGO
}

\section{Wprowadzenie}

Bezpieczeństwo w ruchu drogowym należy do zagadnień, które w bezpośredni sposób dotykają człowieka. Nie ma dzisiaj na świecie miejsc, poza terenami niezurbanizowanymi, w których człowiek nie byłby uczestnikiem ruchu drogowego, zarówno jako kierujący, pasażer, rowerzysta czy pieszy. Każdy rodzaj uczestnictwa w ruchu drogowym, niesie ze sobą określone konsekwencje i wymaga spełnienia określonego minimum, by uczynić to uczestnictwo bezpiecznym.

Statystyki, będące jedynym miarodajnym i zobiektywizowanym kryterium oceny stanu bezpieczeństwa ruchu drogowego są nieubłagane. Za każdą z cyfr policyjnych raportów z dróg kryje się dramat ofiar wypadków i ich rodzin, ale także, o czym często się zapomina, sprawców wypadków, którzy przyczynili się do tragedii. O ile koszty generowane przez wypadki da się policzyć w odniesieniu do procesu leczenia, rehabilitacji oraz świadczeń, o tyle śmierć, trwałe kalectwo czy wyrzuty sumienia, należą do kategorii niepoliczalnej, z którą ofiara lub sprawca wypadku zmagać się musi do końca życia sama.

W 2015 roku na polskich drogach doszło do 32701 wypadków i zdarzeń drogowych. Odnotowano 2904 ofiary śmiertelne i 39457 osób rannych. W tym samym czasie, według danych Komisji Europejskiej, na drogach Unii Europejskiej zginęło 26000 osób, 135000 zostało poważnie rannych. Koszty społeczne (rehabilitacja, opieka zdrowotna, szkody materialne itp.) tych wypadków oszacowano na 100000000000 euro (100 miliardów). Dużą część osób, które w wypadkach drogowych odniosły obrażenia, stanowili piesi i rowerzyści. 
Średni współczynnik śmiertelności w wypadkach drogowych w UE w 2015 r. wyniósł 51,5 na 1 mln mieszkańców.

Najniższe wskaźniki, nieprzekraczające 30 ofiar śmiertelnych na milion mieszkańców, odnotowano na Malcie, w Holandii, Szwecji i w Wielkiej Brytanii. Najwyższy współczynnik śmiertelności na drogach (powyżej 90 na 1 milion mieszkańców) dotyczył Bułgarii, Łotwy, Litwy i Rumunii.

Zaznaczyć trzeba, że z dostępnych dziś danych Komisji Europejskiej wynika jednak, że łączna liczba śmiertelnych ofiar wypadków drogowych w UE spadła od 2010 r. o 18,2\%. W niektórych krajach wskaźnik ten obniżył się w ostatnich latach jeszcze bardziej. Trend ten dotyczy Grecji, Portugalii i Hiszpanii. Również Dania, Chorwacja, Malta, Cypr, Rumunia, Włochy, Słowenia i Republika Czeska odnotowały spadek liczby ofiar na drogach przekraczający średnią dla UE w latach 2010-2014.

Na terenie województwa kujawsko-pomorskiego odnotowano w 2015 r. 965 wypadków, w których zginęło 145 osób, a 1088 zostało rannych. Do kwietnia 2016 r. (styczeń-kwiecień) wydarzyło się 247 wypadków, w których zginęło 46 osób, a 287 zostało rannych. Za tymi liczbami kryją się konkretne dramaty mieszkańców naszego regionu. To najczęściej brawura, nadmierna prędkość, alkohol, środki psychoaktywne, zbytnia wiara we własne umiejętności, brak elementów odblaskowych, czy rozmowy przez telefon komórkowy w czasie jazdy, stały za większością z nich.

Wojewódzki Ośrodek Ruchu Drogowego w Bydgoszczy jest jednym z tych podmiotów, na których spoczywa obowiązek promowania bezpieczeństwa w ruchu drogowym.

\section{Podstawa prawna działalności WORD-ów}

Wojewódzkie Ośrodki Ruchu Drogowego działają na podstawie przepisów ustawy z dnia 20 czerwca 1997 r. Prawo o ruchu drogowym ${ }^{1}$, ustawy z dnia 5 czerwca 1998 r. o samorządzie województwa² oraz Statutu. Wojewódzki Ośrodek Ruchu Drogowego jest wojewódzką samorządową osobą prawną. Bydgoski WORD został powołany przez Wojewodę Bydgoskiego w 1998 r.

Do podstawowych zadań Wojewódzkich Ośrodków Ruchu Drogowego należy organizowanie egzaminów państwowych sprawdzających kwalifikacje

Tekst jedn. Dz.U. z 2017 r., poz. 128.

2 Tekst jedn. Dz.U. z 2016 r., poz. 486. 
osób ubiegających się o uprawnienia do kierowania pojazdami oraz kierujących pojazdami.

\section{Kujawsko-Pomorska Wojewódzka \\ Rada Bezpieczeństwa Ruchu Drogowego}

Ciałem, które koordynuje prace Wojewódzkich Ośrodków Ruchu Drogowego jest Wojewódzka Rady Bezpieczeństwa Ruchu Drogowego. Do jej zadań należy:

a. opracowywanie regionalnych programów poprawy bezpieczeństwa ruchu drogowego;

b. opiniowanie projektów aktów prawa miejscowego w zakresie bezpieczeństwa ruchu drogowego;

c. zatwierdzanie planu wydatków wojewódzkich ośrodków ruchu drogowego w części przeznaczonej na poprawę bezpieczeństwa ruchu drogowego;

d. współpraca z właściwymi organizacjami społecznymi i instytucjami pozarządowymi;

e. inicjowanie działalności edukacyjno-informacyjnej.

\section{Kompetencje Wojewódzkiej}

\section{Rady Bezpieczeństwa Ruchu Drogowego}

Z dniem 1 stycznia 2006 r. dotychczasowe kompetencje wojewody dotyczące Wojewódzkiej Rady Bezpieczeństwa Ruchu Drogowego, w tym m.in. sprawowanie funkcji przewodniczącego, przekazane zostały marszałkowi województwa. Wojewoda w obecnej strukturze Rady pełni funkcję zastępcy przewodniczącego. Wojewódzka Rada koordynuje i określa kierunki działań administracji publicznej w sprawach bezpieczeństwa ruchu drogowego. Do jej zadań należy w szczególności:

a. opracowywanie regionalnych programów poprawy bezpieczeństwa ruchu drogowego;

b. opiniowanie projektów aktów prawa miejscowego w zakresie bezpieczeństwa ruchu drogowego;

c. zatwierdzanie planu wydatków wojewódzkich ośrodków ruchu drogowego w części przeznaczonej na poprawę bezpieczeństwa ruchu drogowego; 
d. inicjowanie kształcenia kadr administracji publicznej i szkolenie w zakresie bezpieczeństwa ruchu drogowego;

e. inicjowanie współpracy międzywojewódzkiej;

f. współpraca z właściwymi organizacjami społecznymi i instytucjami pozarządowymi;

g. inicjowanie działalności edukacyjno-informacyjnej;

h. analizowanie i ocena podejmowanych działań.

\section{Skład Wojewódzkiej Rady Bezpieczeństwa Ruchu Drogowego}

W skład Wojewódzkiej Rady Bezpieczeństwa Ruchu Drogowego wchodzą:

a. przewodniczący - marszałek,

b. zastępcy przewodniczącego:

- wojewoda

- komendant wojewódzki Policji

- sekretarz - wskazany przez marszałka,

c. członkowie Wojewódzkiej Rady:

- wojewódzki inspektor transportu drogowego,

- dyrektor właściwego terenowo oddziału Generalnej Dyrekcji Dróg Krajowych i Autostrad,

- przedstawiciel wojewody,

- przedstawiciel wojewódzkiego sztabu wojskowego,

- przedstawiciel kuratora oświaty,

- przedstawiciel zarządu województwa,

- przedstawiciel zarządów powiatu,

- przedstawiciel wójtów, burmistrzów lub prezydentów miast,

- przedstawiciel komendanta wojewódzkiego Policji,

- przedstawiciel komendanta wojewódzkiego Państwowej Straży Pożarnej,

- przedstawiciel zarządu dróg wojewódzkich,

- przedstawiciel wojewódzkich ośrodków ruchu drogowego,

- przedstawiciel zarządów dróg powiatowych,

- osoby wskazane przez marszałka województwa, w szczególności reprezentujące działające na terenie województwa organizacje pozarządowe, których celem statutowym jest problematyka bezpieczeństwa ruchu drogowego; marszałek województwa może wskazać nie więcej niż 12 osób. 


\section{Egzaminy, jako zadania WORD-ów na przykładzie WORD w Bydgoszczy}

Do podstawowych zadań Wojewódzkich Ośrodków Ruchu Drogowego należy organizowanie egzaminów państwowych sprawdzających kwalifikacje osób ubiegających się o uprawnienia do kierowania pojazdami oraz kierujących pojazdami. W największym w województwie kujawsko-pomorskim Ośrodku Ruchu Drogowego mieszczącym się w Bydgoszczy liczba i zdawalność, jeśli chodzi o egzamin teoretyczny w ubiegłych latach, przedstawiała się następująco:

1. w zakresie egzaminów teoretycznych:

a. 2012 rok - 18260 egzaminów (zdawalność 80,06\%)

b. 2013 rok - 7823 egzaminów (zdawalność 41,17\%)

c. 2014 rok -7085 egzaminów (zdawalność 40,09\%)

d. 2015 rok - 10844 egzaminów (zdawalność 45,34\%)

e. 2016 rok (styczeń-kwiecień) - 3362 (zdawalność 49,24\%)

Prognoza na 2016 rok - 10086 egzaminów.

2. w zakresie egzaminów praktycznych:

a. 2012 rok - 49680 egzaminów (zdawalność 26,29\%)

b. 2013 rok - 38637 egzaminów (zdawalność 25,28\%)

c. 2014 rok - 22254 egzaminów (zdawalność 28,96\%)

d. 2015 rok - 33549 egzaminów (zdawalność 30,16\%)

e. 2016 rok (styczeń-kwiecień) - 13819 egzaminów (zdawalność 27,11\%)

Prognoza na 2016 - 41457 egzaminów.

\section{Kursy i szkolenia organizowane przez WORD w Bydgoszczy}

Wojewódzki Ośrodek Ruchu Drogowego w Bydgoszczy organizuje następujące kursy i szkolenia. W 2015 roku były to:

a. kurs podstawowy na egzaminatora (wydano 4 zaświadczenia);

b. kurs dodatkowy dla egzaminatorów (wydano 4 zaświadczenia);

c. warsztaty doskonalenia egzaminatorów (wydano 34 zaświadczenia);

d. kwalifikacja wstępna kat. C, C+E (wydano 1 zaświadczenie);

e. szkolenie okresowe kat. C, C+E (wydano 34 zaświadczenia);

f. szkolenie okresowe kat. D, D+E (wydano 2 zaświadczenia); 
g. kurs dla nauczycieli egzaminujących na kartę rowerową (wydano 15 zaświadczeń);

h. szkolenie kierowców naruszających przepisy ruchu drogowego (wydano 661 zaświadczeń);

i. kurs kierowania ruchem drogowym (wydano 369 zaświadczeń);

j. kurs reedukacyjny w zakresie problematyki przeciwalkoholowej i przeciwdziałania narkomanii (do lipca 2016 r. wydano 10 zaświadczeń).

Obok zadań związanych z organizowaniem egzaminów sprawdzających kwalifikacje osób ubiegających się o uprawnienia do kierowania pojazdami oraz kierujących pojazdami, organizowania szeregu kursów i szkoleń podnoszących kwalifikacje kierowców, bydgoski WORD prowadzi akcje, których celem jest poprawa bezpieczeństwa w ruchu drogowym. Skierowane są one zarówno do najmłodszych mieszkańców województwa, jak i osób dorosłych. Pracownicy WORD docierają do przedszkoli, szkół, uczestniczą w festynach i imprezach masowych, gdzie informują, instruują i pokazują, jak bezpiecznie poruszać się na drodze i w jej obrębie. WORD organizuje turnieje poświęcone bezpieczeństwu ruchu drogowego (BRD), jak również współuczestniczy w różnego rodzaju konkursach dotyczących bezpiecznej jazdy. Ważnym elementem jest tutaj współpraca z organizacjami pozarządowymi, realizującymi działania na rzecz poprawy bezpieczeństwa w ruchu drogowym.

WORD w Bydgoszczy prowadzi zajęcia lekcyjne w liceum ogólokształcącym w Sępólnie Krajeńskim w klasie o profilu BRD, której był inicjatorem. W 2016 roku organizował Finał Okręgowy XXXIX Ogólnopolskiego Turnieju Bezpieczeństwa w Ruchu Drogowym dla szkół podstawowych i gimnazjów oraz Finał Wojewódzki XX Ogólnopolskiego Młodzieżowego Turnieju Motoryzacyjnego dla szkół ponadgimnazjalnych. Prowadzi zajęcia edukacyjne dla grup przedszkolnych i wczesnoszkolnych z wykorzystaniem zestawu edukacyjnego „Autochodzik”.

W latach ubiegłych bydgoski WORD zainicjował i wsparł finansowo budowę miasteczek ruchu drogowego, m.in. w Dąbrowie Biskupiej, Wojnowie, Nakle nad Notecią, Tucholi, Wtelnie, Kruszwicy, Inowrocławiu, Gniewkowie, Świekatowie, Śliwicach, Warlubiu, Serocku, Nowem, Witoldowie, Kozielcu, Szubinie, Wierzchucinie Królewskim, Mąkowarsku, Sławęcinku, Barcinie, Koronowie i Bydgoszczy (5 szkół). W pełni wyposażył także sale wychowania komunikacyjnego w Kruszynie i Solcu Kujawskim. 
Bezpieczeństwo ruchu drogowego jest tym obszarem, który wymaga nieustannych starań. Wymaga przede wszystkim wyobraźni od uczestników ruchu drogowego. Wystarczy chwila nieuwagi, by dotychczasowe szczęśliwe życie zamieniło się w udrękę. Dlatego każde działanie, nawet najmniejsze, służące poprawie bezpieczeństwa na drogach warte jest wsparcia. W 2016 roku bydgoski WORD zwiększył wydatnie budżet na promocję BRD, uczestnicząc w szeregu imprez masowych i sportowych. W spotach WORD udział biorą znani sportowcy z naszego regionu, promujący bezpieczną jazdę. Wszystko po to, by na drogach naszego regionu było jak najmniej dramatów.

Andrzej Gross Dyrektor Wojewódzkiego Ośrodka Ruchu Drogowego w Bydgoszczy 